\title{
TÁRSADALOMTUDOMÁNY
}

\author{
Urbanovics Anna», Sasvári Péter*
}

\section{Nemzetközi versenyképesség a hadtudománnyal foglalkozó intézmények tudományos teljesítménye tükrében*}

DOI 10.17047/HADTUD.2021.31.3.91

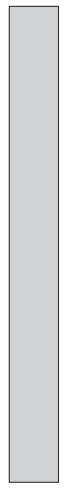

\begin{abstract}
A hadtudomány fejlődése során - specifikus jellegéból adódóan - mindig is kiemelt szerepet töltött be a tudományok között. Egyszerre szolgálja adott állam innovációs potenciálját, valamint az állam katonai feladatainak tervezését. A nemzetközi tudományos versenyképesség növeléséhez érdemes megvizsgálni a külföldi hadtudománnyal foglakozó katonai (védelmi) egyetemeket és akadémiákat tudományos teljesítményük és kutatási portfóliójuk alapján. Az empirikus elemzést 12 egyetem bevonásával végeztük, a nemzetközileg magasan jegyzett (Scimago Journal Rankingindexált) közleményeik alapján vetettük össze publikációs teljesítményüket. A vizsgált intézmények között találtunk olyanokat, amelyek nagy eséllyel pályázhatnának a QS World University Rankings és a Times Higher Education nemzetközi egyetemi rangsorokon való szereplésre is, míg a hazai hadtudományi kutatások - elsósorban a Nemzeti Közszolgálati Egyetem dominanciájával - ezen versenyképes intézményekkel való együttmúködések által növelhetné saját teljesítményét.
\end{abstract}

KULCSSZAVAK: egyetemi kiválóság szerepe, kutatási kiválóság, innováció

\section{International Scientific Competitiveness in Light of the Research and Publication Performances of Institutions of Military Sciences}

In order to increase international scientific competitiveness, it is worth examining military universities and academies worldwide dealing primarily with military sciences based on their research performance and research portfolios. The sample of the empirical analyses

४ Nemzeti Közszolgálati Egyetem, Államtudományi és Nemzetközi Tanulmányok Kar Közigazgatás-tudományi Doktori Iskola, PhD-hallgató - University of Public Service, Faculty of Public Governance and International Studies, Doctoral School of Public Administration Sciences;

e-mail: anna.urbanovics@gmail.com; https://orcid.org/0000-0003-2163-7273

* Nemzeti Közszolgálati Egyetem, Államtudományi és Nemzetközi Tanulmányok Kar University of Public Service, Faculty of Public Governance and International Studies; e-mail: Sasvari.Peter@uni-nke.hu; https://orcid.org/0000-0002-4031-4843

* A tanulmány az Innovációs és Tecnológiai Minisztérium ÚNKP-20-3-1 kódszámú Új Nemzeti Kiválóság Programjának szakmai támogatásával készült. 
contains 12 universities, their publication performance was evaluated based on their internationally recognized (SJR indexed) publications. Among the institutions examined, some own the potential to successfully apply for the QS or THE international university rankings in terms of scientific performance, while the Hungarian military science research with the dominance of the University of Public Service-could increase their performance by the cooperation with these, highly competitive institutions.

KEYWORDS: Role of university excellence, research excellence, innovation

\section{Bevezetés}

A nemzetközi tudományos versenyképesség mérése napjainkban az egyetemek és kutatóintézetek kiemelt prioritása. A tudományos versenyképességet elsósorban tudománymetriai mutatók vagy puha indikátorok mentén vizsgáljuk, de máig meghatározó a közlemény és a rájuk érkező hivatkozások száma és minôsége szerinti teljesítménymérés. A nemzetközi tudományos paradigmaváltásba jól illeszkedik az egyre kiélezôdő verseny, mind a kutatók egyéni, mind az intézmények és országok szintjén. A nemzetközi tudományos paradigmaváltás legjelentôsebb folyamata a tudományos munka „piacosodása”, melynek keretében a szerzók megélhetésüket kötik a kutatómunkához. Ezen szemléletváltás része a tudományos teljesítményértékelés eszközeiben tapasztalható változás is, így a tudományos kiválóságot célzó eszközök - pályázati rendszerek, teljesítményalapú publikációs modellek - elótérbe kerülése is ebbe illeszkedik. A folyamat jelentôs eleme a nemzetközi rangsorok, különösen a jelen tanulmányunk vizsgálati kereteit adó nemzetközi egyetemi rangsorok felértékelődése a tudományos teljesítmény mérhetôvé válásával. Éppen ezért mára presztízs kérdésévé vált a nemzetközi ranglistákon való szereplés, a régióban vagy világon betöltött vezetố szerep egyes kiemelt tudományterületeken.

Tevékenységi körüket illetóen az egyetemek és akadémiai kutatóintézetek bizonyos átfedésekkel múködnek. Míg az elóbbi esetében a tudásmegosztás, utánpótlás nevelés és általában az oktatás jelenti a legfóbb portfóliót, addig a kutatóintézetek számára leginkább az alap- és alkalmazott kutatások végzése, újabb tudományos felfedezések és eredmények elérése a prioritás. ${ }^{1}$ A nemzetközi versenyképesség általánosan elfogadott mérési keretrendszere a nemzetközi egyetemi ranglistákon való szereplés, melyre az egyetemek és oktatói tevékenységgel foglalkozó kutatóintézetek is egyaránt felkerülhetnek.

A tudományos és kutatás-fejlesztési szférában e két szerepló mellett az üzleti szféra vállalatai és a kormányzati, állami szféra is jelentős szerepet játszanak. Ezek együttmúködésének harmóniája rendkívüli prioritás, ugyanakkor a tudományos szakpolitika számára megoldandó kihívás is egyben. A tudományos kiválóság elérése olyan belsó és külsố tényezók függvénye, mint például az adott intézmény alkalmazotti köre, hallgatói (utánpótlás) bázisa, a versenyképes tudományos tevékenységi kör kialakítása. A külső tényezók közé többek között a szereplók közötti együttmúködés, a finanszírozási keretek, valamint a nemzetközi partnerek tartoznak.

A hadtudománynak ebben a rendszerben kiemelt szerepe van, hiszen több fejlesztés, mind a modellezési, mind a technikai megvalósítási szinten hagyományosan

1 Sun 2013. 
a hadiiparhoz kötôdik. ${ }^{2}$ Innen szivárognak tovább a már kipróbált technikai vívmányok a civil vállalatok felé, majd a tömeggyártásba. ${ }^{3}$ Mindezek miatt könnyen beláthatjuk, hogy a hadtudományi profillal rendelkezó kutatási intézmények és egyetemek minden állam számára kulcsfontosságúak a nemzetközi versenyképesség szempontjából, támogatásuk és múködésük jelentôs. Jelen tanulmányban 12 hadtudományi kutatási profillal rendelkező intézményt vetünk össze a tudományos versenyképességük szempontjából az alkalmazott tudománymetria segítségével.

\section{Nemzetközi egyetemi rangsorok indikátorrendszerei}

A nemzetközi teljesítménymérés általánosan elfogadott eszközei az egyetemi rangsorok. Nemzetközi táblás értékelést ad például az QS-, THE-, ARWU- és a Leidenrangsor is. A nemzetközi felsőoktatási rangsorokon szereplés előnye, hogy lehetôséget ad a nemzeti- és nemzetközi összehasonlításra, segíti a leendő hallgatók választását, felhívja a figyelmet a jövóbeni fejlesztések szükségességére. A nemzetközi rangsorok elsósorban az egyetemek kutatási teljesítményére fókuszálnak. A leginkább objektívnek a bibliometriai mutatók tekinthetók, ám ezek egyik fő korlátja, hogy nagyban függnek az intézmény méretétól. Az elemzésben a QS és a THE Times rangsorokat emeljük ki. Mindkettố a Scopus által indexált közleményekre koncentrál a kutatási teljesítmény mérése során. ${ }^{4}$

A QS World University Rankings (QS) egyetemi rangsort a brit Quacquarelli Symonds cég állítja össze minden évben 2004 óta. ${ }^{5} 2004$ és 2009 között a Times Higher Education (THE) céggel közös listát készítettek. ${ }^{6} 2009$ után a két brit cég önálló listát kezdett el összeállítani. A 2014-es rangsor módszertana szerint az alábbi tényezóket vették figyelembe az oktatási intézmények sorrendjének meghatározásakor.

1. táblázat.

QS World University Rankings módszertana

(Forrás: QS Rankings)

\begin{tabular}{|l|l|c|}
\hline \multicolumn{1}{|c|}{ Kategória } & \multicolumn{1}{c|}{ Mutató } & Súly (\%) \\
\hline $\begin{array}{l}\text { A kutatók és oktatók körében kitöltött } \\
\text { globális kérdóív }\end{array}$ & $\begin{array}{l}\text { Kutatók értékelése } \\
\text { az intézmény elismertségéról }\end{array}$ & 40 \\
\hline A tanítás iránti elkötelezettség mérése & Oktató/hallgató arány & 20 \\
\hline Kutatási hatás (Impakt faktor) mérése & Oktatók idézettségei & 20 \\
\hline A végzett hallgatók munkaerópiaci értékelése & Munkaadó elismertsége & 10 \\
\hline A hallgatói közösség sokszínúségének mérése & Nemzetközi hallgatók aránya & 5 \\
\hline Az oktatói közösség sokszínúségének mérése & Nemzetközi oktatók aránya & 5 \\
\hline
\end{tabular}

2 Griffin 2017.

3 Defense Industry at the Heart of Innovation, NDIA. 2019.

https:/www.ndia.org/policy/recent-posts/2019/10/17/defense-industry-at-the-heart-of-innovation (Letöltés ideje: 2020. 11. 22.)

4 Sasvári, Urbanovics 2019, 213.

5 QS World University Rankings by Subject 2020: Methodology Top Universities. https://www.topuniversities.com/subject-rankings/methodology (Letöltés ideje: 2020. 11. 22.)

6 The World University Rankings 2020: methodology Times Higher Education (THE). https://www.timeshighereducation.com/world-university-rankings/world-university-rankings -2020-methodology (Letöltés ideje: 2020. 11. 22.). 
A Times ranglistamellékletét (Times Higher Education - THE) elöször 2004-ben publikálták a britek. A THE több indikátorra épülő eljárással készül, öt kategóriába rendezve összesen 13 mutatót használ, az objektív adatokat kiegészítve közvélemény-kutatási eredményekkel is.

\section{2. táblázat.}

World University Rankings, Times Higher Education (THE) módszertana (Forrás: Times Higher Education - THE)

\begin{tabular}{|l|l|c|}
\hline \multicolumn{1}{|c|}{ Kategória } & \multicolumn{1}{|c|}{ Mutató } & Súly (\%) \\
\hline $\begin{array}{l}\text { Gazdasági aktivitás, } \\
\text { innováció }\end{array}$ & Ipari kutatási bevételek & 2,5 \\
\hline \multirow{4}{*}{$\begin{array}{l}\text { Nemzetközi } \\
\text { vonzeró }\end{array}$} & A külföldi oktatók aránya & 2,5 \\
\cline { 2 - 3 } & A külföldi hallgatók aránya & 2,5 \\
\cline { 2 - 3 } & Külföldi társszerzós cikkek & 2,5 \\
\hline \multirow{5}{*}{ Oktatás } & Az oktatás hírneve & 15,0 \\
\cline { 2 - 3 } & PhD-fokozatúak aránya & 6,0 \\
\cline { 2 - 3 } & Oktató-hallgató arány & 4,5 \\
\cline { 2 - 3 } & PhD-bachelor (BA) arány & 2,25 \\
\cline { 2 - 3 } & Akadémiai bevétel & 2,25 \\
\hline \multirow{5}{*}{ Kutatás } & A kutatás hírneve & 6,0 \\
\cline { 2 - 3 } & Kutatási bevétel & 6,0 \\
\cline { 2 - 3 } & $\begin{array}{l}\text { Oktatók és kutatók } \\
\text { publikációi }\end{array}$ \\
\hline Idézettség & Idézettségi hatás & 30,0 \\
\hline
\end{tabular}

\section{A hadtudomány komplex rendszere}

A hadtudomány tudományos diszciplínaként való tárgyalásával több magyar szerzó is foglalkozott az elmúlt években, fóleg a Nemzeti Közszolgálati Egyetem (NKE) oktatói közül. Gócze István tanulmányában ${ }^{7}$ kifejtette, hogy a tudományok végleges és a tudományos közösség által egyöntetúen elfogadott klasszifikációja nem lehetséges, viszont a szerzó szerint a tudományok rendszerezésével ettól függetlenül foglalkoznunk kell. Ez egyrészt elósegíti a hasonló területeken dolgozó kutatók összegyújtését, másrészt segít kontextusba helyezni az újabb tudományos eredményeket.

Glenn Voelz tanulmánya ${ }^{8}$ szerint a hadtudomány általában az elméletek, modellek és módszertanok azon csoportját jelenti, melyet a haderó alkalmazására használnak. Ha magát a tudományágat tekintjük, akkor már korántsem ilyen egyszerú a helyzet. Ahogy azt Voelz is megállapítja, a hadtudományt sok más tudományág támogatja, ideértve a történelmet, külügyeket és nemzetközi kapcsolatokat, biztonsági tanulmányokat, vezetéselméletet, rendszerüzemeltetést, és további elemeket a természettudományok és társadalomtudományok területéról. A hadtudomány, mint fogalom használata a 19. században terjedt el, amikor a tudományágat számos

7 Gốcze 2014.

8 Voelz 2014, 84-90. 
helyen a filozófia és fizika mellett említették. ${ }^{9}$ A hadtudományban használt tudományos fogalmak és terminusok leírásának igényét és formalizált rendszerben való használatát az elsó tisztképzók elindulása ösztönözte. Egy másik tényezố a hadtudomány kialakulásában az iparosodási folyamatok gyors kibontakozása volt, ami mind a tudomány, mind a technológia szempontjából központi helyre emelte az amerikai hadi potenciált. A hadtudomány egyszeriben tehát múvészetból tudománnyá alakult. ${ }^{10} \mathrm{~A}$ hadtudomány múvelésének nemzetközi irányzatai nagyban függnek az adott ország geopolitikai, geostratégiai sajátosságaitól és katonai feladataitól. A „Big3” (USA, Oroszország, Kína) államok hat stratégiai irányzatot határoznak meg: ${ }^{11}$

- stratégiai vezetés,

- a jövố fegyveres erói,

- a hibrid hadviselés kihívásai,

- a haderók humán kérdései,

- a modern technológia alkalmazása a haderóben,

- regionális geopolitikai válságok.

A tudomány képes saját magát is, az általa használt fogalom-rendszerrel, módszertannal vagy elméleti alapokkal „önmeghatározni” és egyfajta klasszifikációt kialakítani. Ezt láthatjuk a hadtudomány esetében is, ahol Gócze ${ }^{12}$ az MTA Hadtudományi Bizottsága által indexált folyóiratok rovatai mentén állapította meg a legfóbb csoportosítási rendszert.

Az 1. ábrán látható csoportosítás a hadtudományhoz kapcsolódó legfontosabb kérdésköröket és tudományágakat is kijelöli számunkra. A katonai mellett nem katonai és multidiszciplináris alágakat is találunk. A hadtudomány hasonló kategorizálását adja Munk Sándor is. ${ }^{13}$ Érdemes azt azonban rögzíteni, hogy ezek egymás között nem alkotnak hierarchikus rendszert.

A hadtudomány, mint tudományág számos más tudományterület és tudományág elméletét, módszertanát, illetve eredményeit felhasználva hozza létre saját ismeret-, eredmény-, továbbá tevékenységi rendszerét. Ezeket a kutató és intézmény profiljának megfelelóen párosítja, kidomborítva a céljainak leginkább megfelelót. A hadtudomány Magyarországon is komplex tudományágat alkot. Általában hadtudomány alatt az angolszász, fóleg amerikai származású hadászati ismereteket értjük, de nagymértékben épít a regionális nagyhatalmak hadászati kultúrájára is. Boda és szerzótársai. ${ }^{14}$ tanulmánya rögzíti, hogy a hadtudományi kutatások nem feledkezhetnek meg a legfóbb prioritásokról ,jelen, illetve a jövő háborúinak, katonai konfliktusainak fegyveres erővel és képességekkel történó eredményes és hatékony megvívásáról". Emellett rámutat, hogy az IFT (intézmény fejlesztési terv) külön is kiemeli a hadtudomány specifikus jellegét, amely szerint az egyetemnek tekintettel kell lenni az MH és a rendvédelmi szervek feladataira, sajátos szolgálati és életviszonyaira, valamint az egyes hivatásrendek képzési és kiképzési rendszereiben előzetesen megszerzett ismereteire is.

\footnotetext{
9 Grissom 2006.

10 Voelz, 2014, ism.

11 Boda, Boldizsár, Kovács, Orosz, Padányi, Resperger, Szenes 2016.

12 Göcze 2015.

13 Munk 2015.

14 Boda et al. 2016.
} 


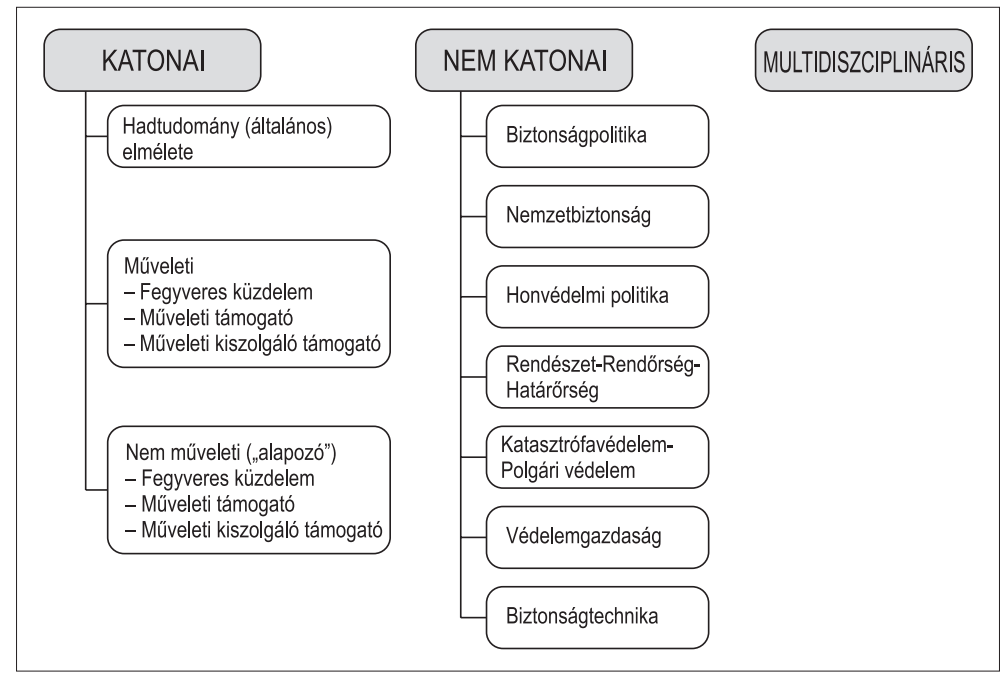

1. ábra.

Hadtudomány tudományterületi bontása

(Gö́cze 2015-ös cikke alapján)

\section{A kutatás menete}

Az empirikus elemzésbe 12, jelentős hadtudományi profillal rendelkezó intézményt vontunk be. Ezek a következók:

1. Instituto Militar de Engenharia (IME) (Brazilia, BG)

2. Military Polytechnic School (MPS) (Algéria, DZ)

3. Military Technical Academy (MTA) (Románia, RO)

4. Military Technical College (MTC) (Egyiptom, ET)

5. Military University of Technology Warsaw (MUTW) (Lengyelország, PL)

6. Nemzeti Közszolgálati Egyetem/University of Public Service (NKE, UPS) (Magyarország, HU)

7. Nikola Vaptsarov Naval Academy (NVNA) (Bulgária, BR)

8. Royal Military Academy (RMA) (Belgium, B)

9. United States Air Force Academy (USAFA) (USA)

10. United States Military Academy at West-Point (WESTPOINT) (USA)

11. United States Naval Academy (USNA) (USA)

12. Walter Reed Army Institute of Research (WRAIR) (USA)

Az intézmények kiválasztásánál az alábbi szempontokat vettük figyelembe:

- rendelkezzen Scopus és Scival azonosítóval,

- fô kutatási és oktatási tevékenysége a hadtudomány legyen, lehetóleg más tevékenységgel ne foglalkozzon,

- az intézmény nevében jól azonosíthatóan szerepeljen a hadtudományi jelleg (például Military, Militar, Naval, Air Force, Army),

- több intézmény esetén a magasabb Scopus által indexált közleménnyel rendelkező szerepeljen a vizsgálatban. 
Az intézmények között 4 amerikait, 1 nyugat-európait, 2 afrikait, 1 dél-amerikait és 4 közép-kelet-európait találunk. Ezen egyetemek többsége saját országukban vezetố - vagy egyedüli - szerepet tölt be a hadtudományi kutatásokban. Magyarországon a felsőoktatási intézmények közül egyedülálló módon az NKE Hadtudományi és Honvédtisztképzố Kara folytat specifikusan hadtudományi kutatásokat, tehát monopolhelyzetben van hazánkban. Ezzel együtt fontos kiemelnünk, hogy mint ahogy azt már korábban ismertettük, ezen intézmények saját hadipari kutatás-fejlesztésükben is élen járnak, szerepük tehát vitathatatlan.

A vizsgálataink során statisztikai eszközökkel elemeztük tudományos és publikációs teljesítményüket, majd ezeket a QS és a THE rangsorok kalkulált indikátoraihoz mértük. A publikációs teljesítmény számításakor a Scopus citációs adatbázisban szereplő közleményekre és hivatkozásokra építettünk. A Scopus az SJR szerinti kvartilis beosztást követi. Az SJR szerinti besorolások használata számos értékelő rangsor, például a QS és a THE Times nemzetközi egyetemi rangsorok részét képezik, ezért a versenyképesség mérésére használt eszköz. Emellett nyíltan hozzáférhető mutató. A folyóiratok (ezen keresztül pedig a cikkek) SJR-értékük szakterületi kategórián belüli rangsora alapján négy, azonos méretú osztályba sorolva jelennek meg, a rangsor felső $25 \%$-ától kezdve a rangsor végén elhelyezkedő 25\%-kal bezárólag. Ez az ún. kvartilis-besorolás: Q1: legjobb 25\%; Q2: 25-50\%; Q3: 50-75\%; Q4: 75-100\% teszi lehetóvé, hogy a különbözó tudomány- és szakterületekhez tartozó folyóiratok és cikkek közvetlenül (vagyis a saját területükön elfoglalt pozíciójuk alapján) összemérhetók legyenek.

Az elemzés teljesebb megértéséhez a h5-index és tudományterületi súlyozott hatás fogalmainak pontos jelentését érdemes ismernünk. A h5-index mutató az utóbbi 5 lezárt évben megjelent közlemények h-indexét mutatja. A h-index olyan mutató, mely szerint az intézménynek pontosan $\mathrm{h}$ darab olyan közleménye van, melyekre egyenként legalább h számú hivatkozás érkezett. A tudományterületi súlyozott hatás az egy publikációra esó átlagos, súlyozott hivatkozásszám összehasonlítva az azonos szakterület átlagos hivatkozásszámával.

\section{Kutatási eredmények}

Empirikus vizsgálatunkban a kiválasztott, hadtudománnyal foglalkozó intézmények publikációs teljesítményét és tudományos tevékenységét, jellemzóit vetettük össze. Eredményeink kiemelik azokat a nemzetközi jó gyakorlatokat, amelyeket a hazai hadtudománnyal foglalkozó közösségnek is figyelembe érdemes vennie.

\section{Publikációs teljesítmény leíró statisztikája}

A 2. ábra (lásd a következố oldalon) a vizsgált intézmények publikációs teljesítményét mutatja az abszolút közleményszám és hivatkozási szám tekintetében.

A listavezetô intézmények az Egyesült Államokból kerülnek ki (USAFA és WRAIR), míg a 3. helyen a lengyel intézmény szerepel. Az UPS (NKE) 216 közleménnyel és a rájuk érkezó 411 hivatkozással a lista utolsó elótti helyén áll. Szembeötlő, hogy a lista első felében az USA egyetemei és akadémiái szerepelnek, ezeket követik a többi ország hasonló profilú intézményei. 


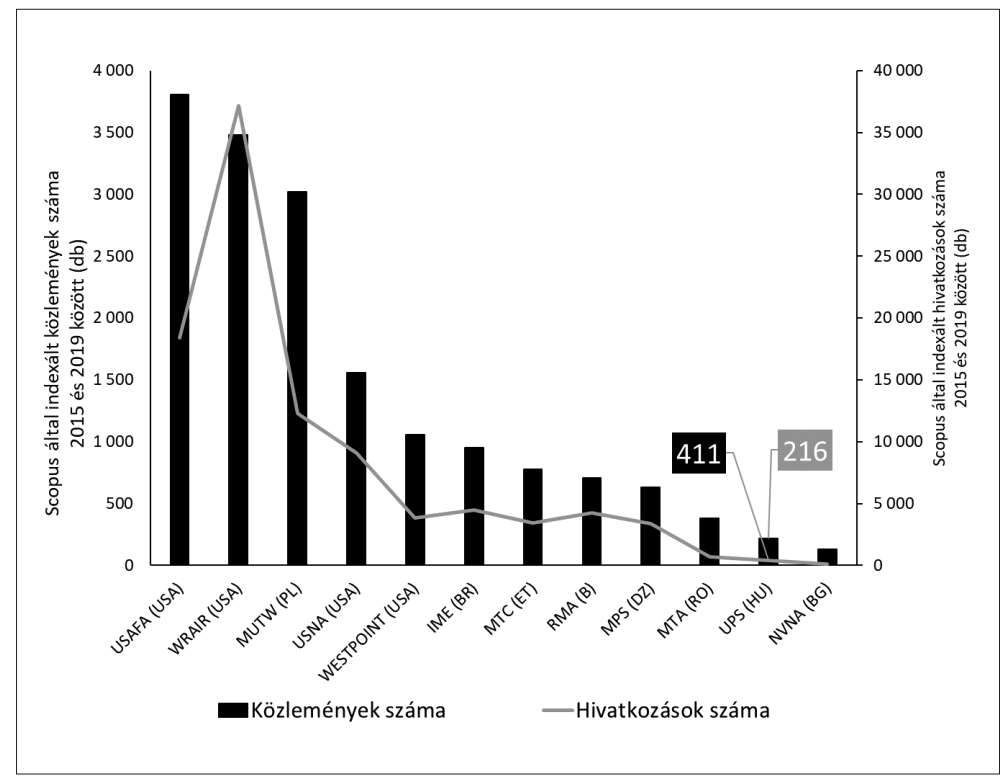

2. ábra.

Közlemények és azokra érkezett hivatkozások száma 2015 és 2019 között (Forrás: saját szerkesztés Scival adatok alapján)

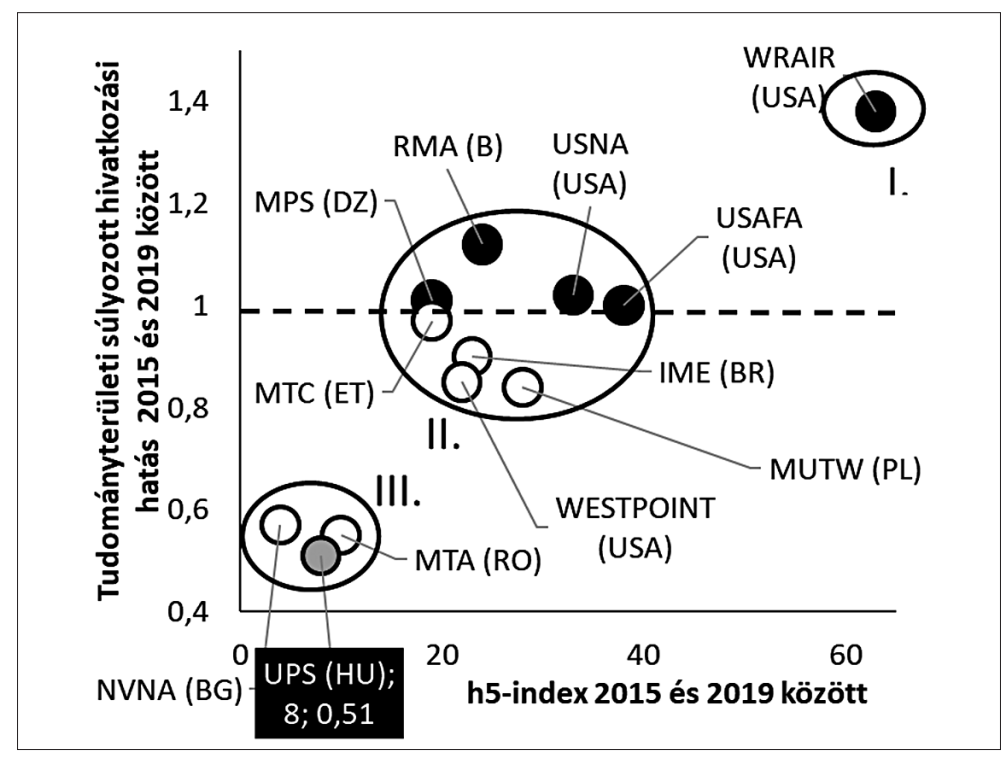

3. ábra.

Tudományterületi súlyozott hivatkozási hatás és h5-index a hadtudománnyal foglalkozó intézményeknél 2015 és 2019 között

(Forrás: saját szerkesztés Scival adatok alapján) 
A 3. ábrán a vizsgált intézmények publikációs teljesítményét láthatjuk a tudományterületi súlyozott hivatkozási hatás és a h5-index tekintetében. Ezek alapján az intézmények három kategóriáját határoztuk meg. A legerósebb intézmény a WRAIR amerikai intézet, ami teljesítményével messze kiemelkedik. A 2. csoportban a további amerikai, tengerentúli és nyugat-európai intézményeket találjuk. A tudományterületi súlyozott hivatkozási hatás szerint egynél magasabb értékkel is 4-4 egyetem rendelkezik. Végül, a 3. kategóriában a közép-kelet-európai egyetemeket figyelhetjük meg a többiektól elmaradó publikációs teljesítménnyel. Ez utóbbiba tartozik az NKE is.

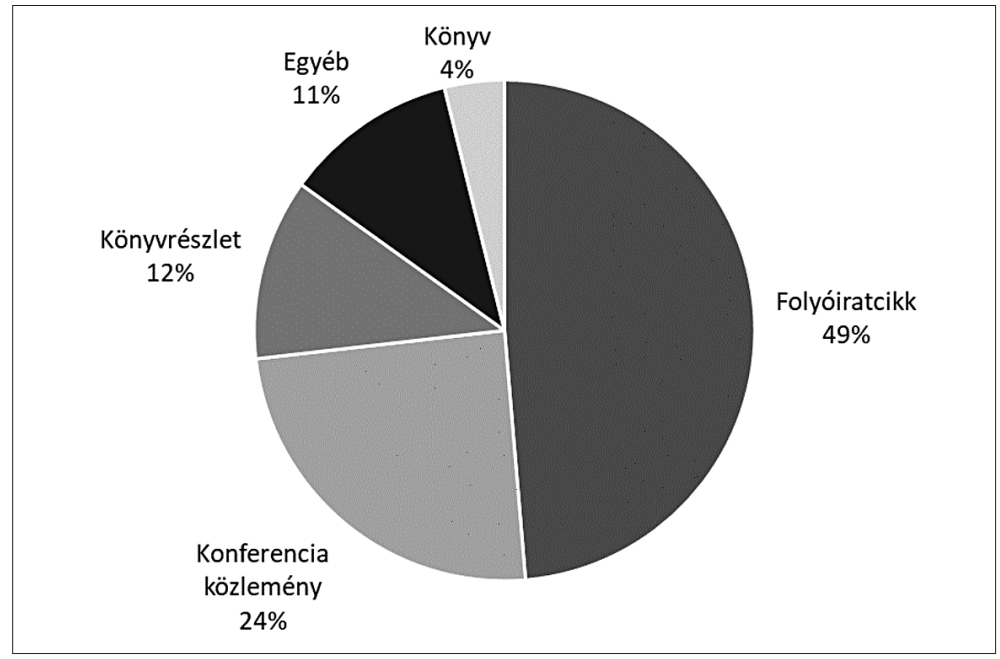

4. ábra.

Hadtudománnyal foglalkozó egyetemek, akadémiák és kutatóközpontok közleményeinek megjelenési típusai társadalomtudomány esetén

(Forrás: saját szerkesztés Scopus adatok alapján)

A 4. ábra a vizsgált intézmények társadalomtudományi publikációinak típus szerinti megoszlását mutatja. Kitúnik, hogy a legtöbb közlemény folyóiratokban jelenik meg. A folyóiratközlemények száma 49\% -ot tesz ki, a közlemények másik felén a konferenciaközlemények, könyvrészletek, könyvek és egyéb besorolású múvek osztoznak. Ebból kitúnik a hadtudomány STEM (Science, technology, engineering, and mathematics) tudományokhoz való szoros kötődése, mert hagyományosan mind a folyóiratpublikáció, mind a konferenciaközlemények írása ezekhez a területekhez kötódik. Ebból is kiemelhetjük a múszaki tudományokat, ami pontosan ezt a szokást követi.

A 3. táblázat a vizsgált intézmények körében legnépszerúbb konferenciaköteteket foglalja össze. A további listákkal összevetve megfigyelhetjük, hogy a konferenciaközlemények jól meghatározhatóan bizonyos konferenciakötetek köré csoportosulnak. Közülük is kiemelkedik a Proceedings Frontiers in Education Conference 73 közleménnyel, melyet a 2. helyen a Proceedings of the Human Factors and Ergonomics Society követ 63 közleménnyel. Ez megmutatja azokat a jól bevált konferenciákat, ahol a hadtudósok általában nagy számban képviseltetik magukat. Érdemes 
3. táblázat.

Hadtudománnyal foglalkozó egyetemek, akadémiák és kutatóközpontok társadalomtudománnyal foglalkozó kutatóinak legjelentốsebb konferenciái

(Forrás: saját szerkesztés Scopus adatok alapján)

\begin{tabular}{|c|l|c|}
\hline Sorszám & \multicolumn{1}{|c|}{ Konferenciakötet címe } & $\begin{array}{c}\text { Közlemények } \\
\text { száma }(d b)\end{array}$ \\
\hline 1 & Proceedings Frontiers In Education Conference & 73 \\
\hline 2 & Proceedings Of The Human Factors And Ergonomics Society & 63 \\
\hline 3 & Proceedings Frontiers In Education Conference Fie & 56 \\
\hline 4 & $\begin{array}{l}\text { International Archives Of The Photogrammetry Remote Sensing } \\
\text { And Spatial Information Sciences ISPRS Archives }\end{array}$ & 45 \\
\hline 5 & Wit Transactions On The Built Environment & 17 \\
\hline 6 & Transportation Research Procedia & 14 \\
\hline 7 & PS Political Science And Politics & 3 \\
\hline 8 & Annual Forum Proceedings American Helicopter Society & 3 \\
\hline 9 & Lecture Notes In Control And Information Sciences & 3 \\
\hline 10 & Lecture Notes In Geoinformation And Cartography & \\
\hline 11 & Proceedings ACM SIGUCCS User Services Conference & 3 \\
\hline
\end{tabular}

ezen közlési helyeket és lapokat a hazai hadtudományos közösségnek is priorizálni, mert a nagy közleményszám egy igen aktív tudományos párbeszédre utal.

A 4. táblázat az elôző táblázathoz hasonlóan a legnépszerúbb megjelenési felületeket listázza, különös tekintettel a folyóiratokra. Az ezen a listán szereplő folyóiratok mindegyike SJR által indexált és rangsorolt, némelyikük pedig Web of Science indexálással is rendelkezik. Ezen lapok tehát elsősorban a nemzetközi tudományos közösség legfontosabb megjelenési helyei, a hadtudomány múvelói által folytatott aktív diskurzusok helye. Szerzóinknek így ezeket érdemes elótérbe helyezniük, így pedig nemzetközi tudományos láthatóságot szerezhetnek eredményeiknek. Ezen folyóiratok aktív olvasása során a hazai hadtudósok valós képet szerezhetnek a legjelentôsebb kutatási témákról, együttmúködési lehetőségeket építhetnek a többi intézménnyel, valamint végsố soron nemzetközi versenyképességüket is növelhetik.

A lista vezetố lapjai a fizika és a pszichológia területéról kerülnek ki. Jól látszik viszont, hogy a lista a múszaki vagy természettudományhoz köthetố és társadalomtudományi lapokat egyaránt tartalmaz. A legnépszerúbbek közöttük Q1-es és Q2-es kvartilissel rendelkeznek, tehát a tudományág csúcsán állnak. A 34 címet tartalmazó lista utolsó helyein találunk az alsóbb kvartilisekben indexált Q3-as lapokat is.

\section{A vizsgált intézmények nemzetközi versenyképességének mérése}

A nemzetközi tudományos versenyképességet általában a nemzetközi egyetemi rangsorok indikátorai mentén mérjük. Jelen fejezetben az elemzett intézményeket a QS és a THE rangsor által használt indikátorok mentén vetjük össze. Érdemes azt viszont figyelembe venni, hogy jelenleg egyik vizsgált intézmény sem szerepel ezen rangsorokban. 
4. táblázat.

Hadtudománnyal foglalkozó egyetemek, akadémiák és kutatóközpontok társadalomtudománnyal foglalkozó kutatóinak legjelentôsebb folyóiratai

(Forrás: saját szerkesztés Scopus adatok alapján)

\begin{tabular}{|c|c|c|c|c|c|}
\hline $\begin{array}{l}\text { Sor- } \\
\text { szám }\end{array}$ & Név & $\begin{array}{c}\text { Típus, } \\
\text { folyóiratnál } \\
\text { kvartilis } \\
\end{array}$ & $\begin{array}{l}\text { Sor- } \\
\text { szám }\end{array}$ & Név & $\begin{array}{l}\text { Típus, } \\
\text { folyóiratnál } \\
\text { kvartilis }\end{array}$ \\
\hline 1 & Physics Teacher & Q2 & 18 & Survival & Q1 \\
\hline 2 & $\begin{array}{l}\text { International Archives } \\
\text { Of The Photogrammetry } \\
\text { Remote Sensing And } \\
\text { Spatial Information } \\
\text { Sciences ISPRS Archives }\end{array}$ & $\begin{array}{l}\text { Konferen- } \\
\text { cia közle- } \\
\text { mény }\end{array}$ & 19 & Water & Q1 \\
\hline 3 & Military Psychology & Q2 & 20 & Archives Of Transport & Q2 \\
\hline 4 & Armed Forces And Society & Q2 & 21 & Business Lawyer & Q2 \\
\hline 5 & Journal Of Military Ethics & Q3 & 22 & $\begin{array}{l}\text { Computer Law And } \\
\text { Security Review }\end{array}$ & Q1 \\
\hline 6 & $\begin{array}{l}\text { Proceedings Of The } \\
\text { Human Factors And } \\
\text { Ergonomics Society }\end{array}$ & $\begin{array}{c}\text { Konferen- } \\
\text { cia közle- } \\
\text { mény }\end{array}$ & 23 & $\begin{array}{l}\text { Defence And Peace } \\
\text { Economics }\end{array}$ & Q2 \\
\hline 7 & Hispania & Q2 & 24 & Democracy And Security & Q3 \\
\hline 8 & $\begin{array}{l}\text { ISPRS International } \\
\text { Journal Of Geo Information }\end{array}$ & Q1 & 25 & $\begin{array}{l}\text { Economics Of Education } \\
\text { Review }\end{array}$ & Q1 \\
\hline 9 & $\begin{array}{l}\text { Journal Of Chemical } \\
\text { Education }\end{array}$ & Q2 & 26 & Foreign Language Annals & Q1 \\
\hline 10 & Sustainability & Q2 & 27 & $\begin{array}{l}\text { Hungarian Journal } \\
\text { Of Legal Studies }\end{array}$ & Q3 \\
\hline 11 & $\begin{array}{l}\text { Transportation Research } \\
\text { Procedia }\end{array}$ & $\begin{array}{c}\text { Konferen- } \\
\text { cia közle- } \\
\text { mény }\end{array}$ & 28 & $\begin{array}{l}\text { Journal Of Cognitive } \\
\text { Engineering And } \\
\text { Decision Making }\end{array}$ & Q2 \\
\hline 12 & $\begin{array}{l}\text { AIDS Care Psychological } \\
\text { And Socio Medical } \\
\text { Aspects Of AIDS HIV }\end{array}$ & Q1 & 29 & $\begin{array}{l}\text { Military Behavioral } \\
\text { Health }\end{array}$ & - \\
\hline 13 & $\begin{array}{l}\text { Advances In Military } \\
\text { Geosciences }\end{array}$ & N. A. & 30 & $\begin{array}{l}\text { Nispacee Journal Of } \\
\text { Public Administration } \\
\text { And Policy }\end{array}$ & Q3 \\
\hline 14 & Society & Q3 & 31 & $\begin{array}{l}\text { Papers Of The } \\
\text { Bibliographical Society } \\
\text { Of America }\end{array}$ & Q4 \\
\hline 15 & $\begin{array}{l}\text { Studies In Conflict And } \\
\text { Terrorism }\end{array}$ & Q1 & 32 & Primus & Q3 \\
\hline 16 & $\begin{array}{l}\text { Association For Women } \\
\text { In Mathematics Series }\end{array}$ & $\begin{array}{l}\text { Book } \\
\text { Series }\end{array}$ & 33 & Revista Transilvania & Q3 \\
\hline 17 & Physics Education & Q2 & 34 & $\begin{array}{l}\text { Studies In Systems } \\
\text { Decision And Control }\end{array}$ & Q3 \\
\hline
\end{tabular}




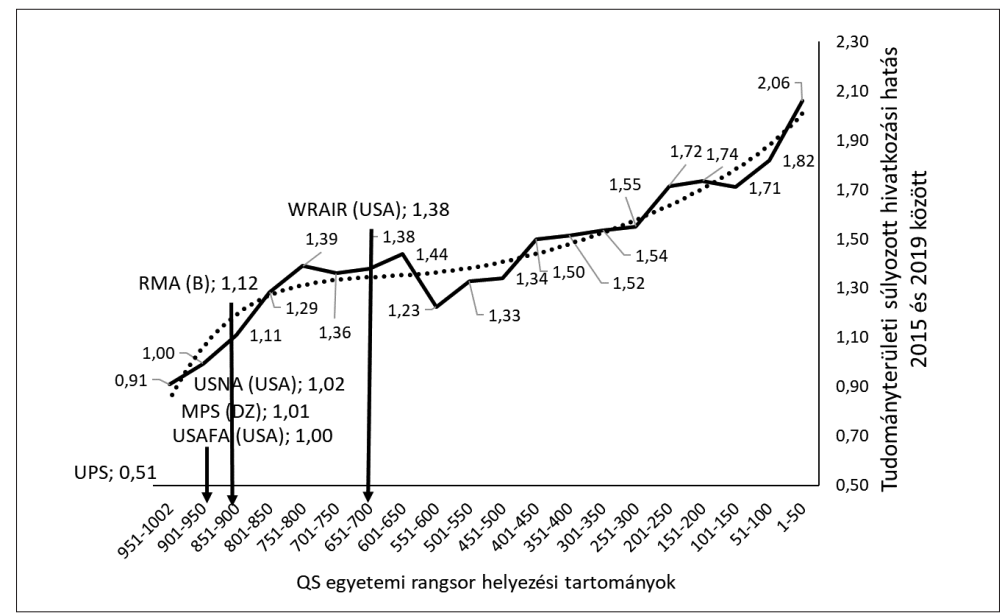

5. ábra.

Tudományterületi súlyozott hivatkozási hatás 2015 és 2019 között és a QS egyetemi rangsor (Forrás: saját szerkesztés QS módszertan és Scival adatok alapján)

Az 5. ábra a vizsgált intézmények teoretikus helyezését mutatja a tudományterületi súlyozott hivatkozási hatás alapján. A QS rangsorban a jelenleg rajta szereplő listás intézmények adatai alapján könnyedén számíthatók azok az értékek, amelyek a helyezés eléréséhez, valamint az egyes helyezési tartományokhoz szükségesek. Ezek alapján kitúnik, hogy a Walter Reed Army Institute of Research (USA) 1,38-as értékkel a 651-700. hely valamelyikére is bekerülhetne. A listára ezen indikátor szerint további két amerikai, egy algériai és egy belga egyetem kerülhetne fel. Az NKE referenciapontként 0,52-es értékkel nem végezne az ezer, listás intézmény között.

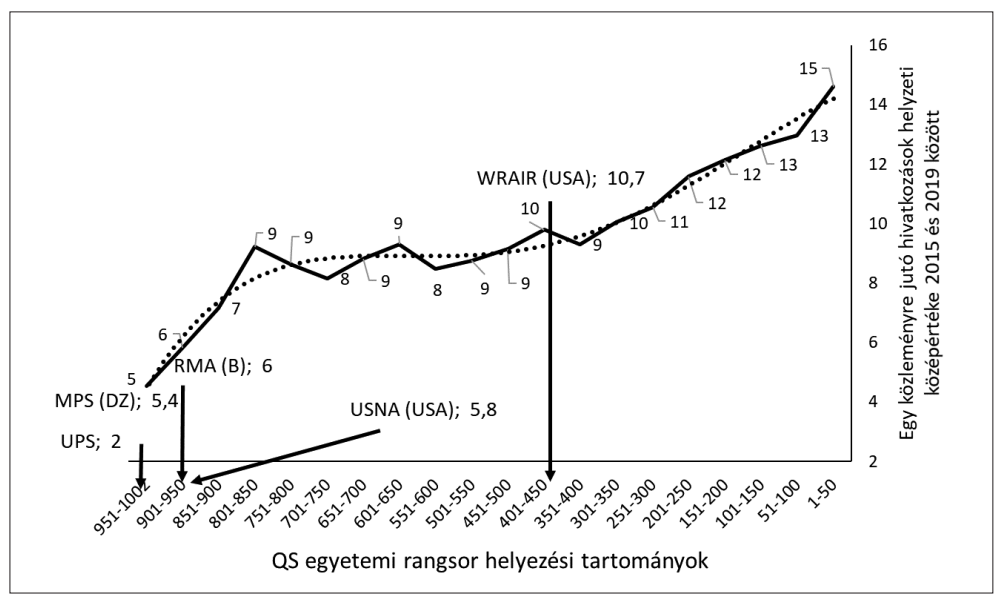

6. ábra.

Egy közleményre jutó hivatkozások 2015 és 2019 között és a QS egyetemi rangsor (Forrás: saját szerkesztés QS módszertan és Scival adatok alapján) 
A 6. ábra hasonló logikával az egy közleményre jutó hivatkozások helyzeti középértékének (mediánjának) számításával helyezi el az egyetemeket. Ebben a tekintetben a Walter Reed amerikai intézet 10,7-es értékkel esélyesen pályázhatna a 401-450. hely valamelyikére. A listára további egy amerikai, egy algériai, és egy belga intézmény kerülne fel, a 901-950. és a 951-1000. helyre. Az NKE 2-es értékkel ezen indikátor szerint sem lenne listás intézmény.

A QS lista után a THE rangsort vizsgáljuk a táblázat sorai alapján.

\section{5. táblázat.}

Times Higher Education (THE) publikációs minimum követelményeinek teljesülése a hadtudománnyal foglalkozó egyetemeknél

(Forrás: saját szerkesztés THE módszertan és Scival adatok alapján)

\begin{tabular}{|c|c|c|c|c|c|c|c|c|c|c|c|c|}
\hline Intézmény ${ }^{15}$ & $A H$ & $B A M$ & СРAH & $C S$ & $E D U$ & EAT & Law & $L S$ & PS & PSY & SS & $\begin{array}{c}\text { Össze- } \\
\text { sen }\end{array}$ \\
\hline USAFA (USA) & 102 & 75 & 768 & 557 & 48 & 1985 & 16 & 240 & 1591 & 74 & 219 & 5675 \\
\hline MUTW (PL) & 12 & 24 & 57 & 849 & 2 & 2234 & 1 & 134 & 1952 & 1 & 126 & 5392 \\
\hline WRAIR (USA) & 41 & 4 & 2927 & 30 & 29 & 70 & 2 & 1028 & 97 & 150 & 49 & 4427 \\
\hline USNA (USA) & 81 & 42 & 88 & 277 & 53 & 634 & 15 & 109 & 857 & 19 & 133 & 2308 \\
\hline $\begin{array}{l}\text { WEST-POINT } \\
\text { (USA) }\end{array}$ & 101 & 94 & 162 & 187 & 55 & 374 & 22 & 118 & 315 & 42 & 192 & 1662 \\
\hline IME (BR) & 5 & 11 & 64 & 169 & 3 & 642 & 0 & 78 & 488 & 0 & 28 & 1488 \\
\hline MTC (ET) & 0 & 4 & 24 & 232 & & 609 & 1 & 17 & 357 & 0 & 13 & 1257 \\
\hline MPS (DZ) & 1 & 6 & 5 & 310 & & 440 & 0 & 9 & 318 & 0 & 5 & 1094 \\
\hline RMA (B) & 3 & 15 & 52 & 142 & 3 & 283 & 3 & 24 & 453 & 9 & 31 & 1018 \\
\hline MTA (RO) & 11 & 2 & 23 & 185 & 1 & 251 & 1 & 6 & 208 & 0 & 25 & 713 \\
\hline UPS (HU) & 15 & 28 & 33 & 22 & 6 & 37 & 26 & 10 & 81 & 6 & 84 & 348 \\
\hline NVNA (BG) & 6 & 4 & 7 & 21 & 29 & 89 & 0 & 6 & 41 & 0 & 35 & 238 \\
\hline Összesen & 390 & 333 & 4267 & 3830 & 231 & 9882 & 88 & 1913 & 8710 & 302 & 1066 & 31012 \\
\hline $\begin{array}{c}\text { Jel- } \\
\text { magyarázat }\end{array}$ & 768 & \multicolumn{5}{|c|}{$\begin{array}{c}\text { Minimum feltételeknek } \\
\text { megfelel }\end{array}$} & 16 & \multicolumn{5}{|c|}{$\begin{array}{c}\text { Minimum feltételeknek } \\
\text { NEM felel meg }\end{array}$} \\
\hline
\end{tabular}

Az 5. táblázaton kitúnnek azon indikátorok, amelyeket a vizsgált intézmények teljesítenek a THE rangsor szerinti értékelésben. Az indikátorok az egyes tudományterületeken elvárt nemzetközileg jegyzett SJR-indexált közleményszámokat mutatják, valamint az utolsó oszlopban az általános lista közleményszámát is láthatjuk. Az általános listára a vizsgált intézmények közül csak a román, a bolgár és magyar egyetem nem kerülne be. Ez ismét rávilágít a kelet-közép-európai intézmények jelentôs hátrányára. A legtöbb tudományterületi listára a United States Air Force Academy kerülne fel (klinikai és pre-klinikai orvostudományok; informatika; múszaki tudomány és technológia; fizika; társadalomtudomány). Ezt követi 3-3 tudomány-

15 Rövidítések: $\mathrm{AH}=$ Arts and Humanities; $\mathrm{BAM}=$ Business and Economics; $\mathrm{CPAH}=\mathrm{Clinical}$, pre-clinical and health; $\mathrm{CS}=$ Computer Science; EDU=Education; $\mathrm{EAT}=$ Engineering and Technology; Law=Law; LS=Life Sciences; PS=Physical Sciences; PSY=Psychology; SS=Social Sciences. 
területi listára való kerülés lehetôségével a lengyel intézmény és a Walter Reed. A további, potenciálisan a listán szereplố egyetem között még egy amerikait találunk, valamint a brazil és egyiptomi is rendelkezik a szükséges közleményszámokkal. A tudományterületi listák bontásában a legtöbb intézmény a múszaki tudomány és technológia (öt intézmény), illetve a fizika (három intézmény) tudományához köthetố profillal rendelkezik. Az NKE számára az ezeken a tudományterületeken megvalósított nemzetközi kutatási együttmúködések további közleményeket eredményezhetnek, és ezzel a listára jutás lehetôségét hordozzák magukban.

\section{Intézmények közötti együttmúködési lehetôségek}

Az NKE szerzóinek pozicionálásához elengedhetetlen saját kutatási profilunk feltérképezése, valamint együttmúködési kereteink meghatározása.

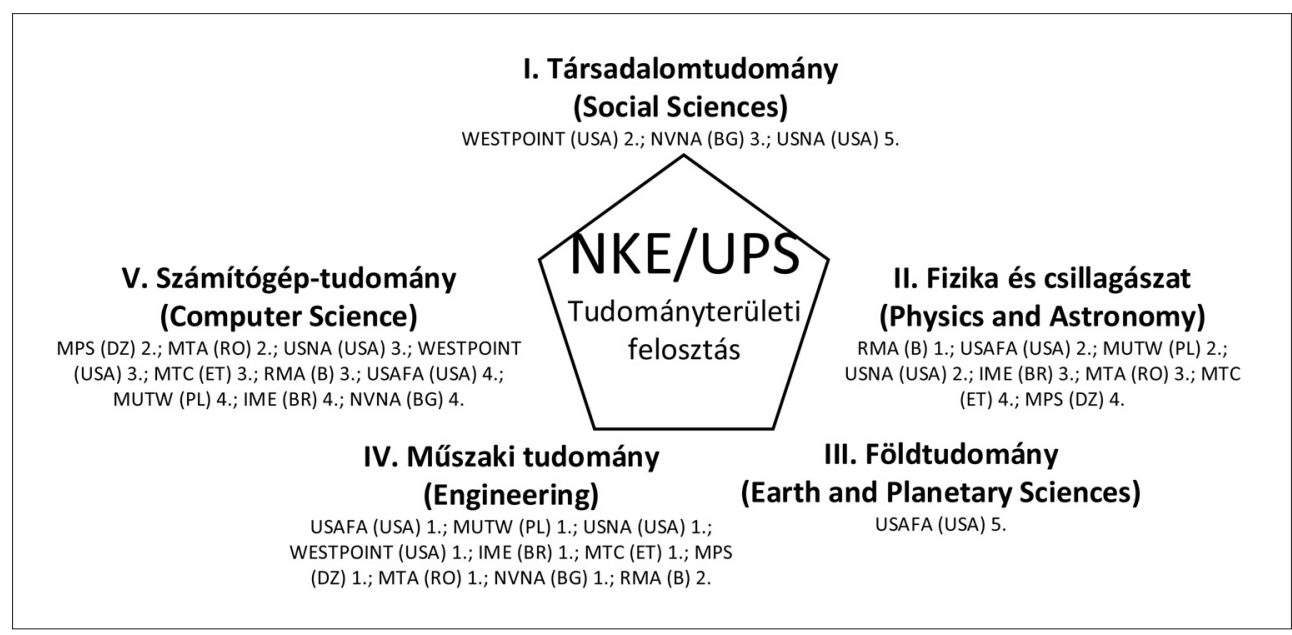

\section{7. ábra.}

A Nemzeti Közszolgálati Egyetem tudományterületi felosztása és a hadtudománnyal foglalkozó intézetek

(Forrás: saját szerkesztés Scival adatok alapján)

Az NKE tudományterületi felosztása szerint öt tudományterületet azonosítottunk. Ezek között jól látszanak a hagyományosan a katonai akadémiák által kedvelt és népszerú területek, mert ezeket a vizsgált intézmények körében is megtaláljuk. A kutatási profiljukat tekintve a legtöbb egyetem a múszaki tudományhoz kapcsolódik, majd az informatika, a fizika és csillagászat területei következnek. Specifikusan mindössze néhány egyetem foglalkozik földtudománnyal és társadalomtudománnyal. Az elemzett intézmények kutatási profiljainak megoszlása azért is fontos, hogy az NKE különböző tudományterületeken aktív szerzói megtalálják a kutatási együttmúködési lehetốségeket.

A tudományterületek mellett a publikációs teljesítmény és közleményszámok alapján kiemelkedő témakategóriákat is azonosíthatjuk (lásd a Mellékletben). Jelen 
tanulmány szerzói nem foglalkoznak hadtudománnyal, ezért a témakategóriák szakzsargonjának pontos fordítására nem vállalkoznak. Az adatok alapján megfigyelhetünk bizonyos trendeket, melyeket követve az NKE szerzói is sikerrel szállhatnának be a nemzetközi diskurzus folyamatába. Az összefoglaló táblázat értelmezésekor a tudományterületre súlyozott hivatkozási hatás azt mutatja, hogy adott kategória közleményei a hasonló kategóriák közleményeihez képest mennyire hivatkozottak, míg a népszerúségi index adott témakategória relatív aktivitását mutatja (ebból következtethetünk az adott téma felkapottságára). Az egyetemek fóbb profiljai a következók azok esetében, ahol ezt meg tudtuk állapítani:

- IME (BG) - logisztika, tudásmenedzsment, gazdálkodás- és szervezéstudományok

- NVNA (BR) - haditengerészet, kiemelt téma a kiberbiztonság

- MPS (DZ) - híradástechnika

- RMA (B) - katasztrófavédelem és -elhárítás, krízismenedzsment

- MTA (RO) - ipari együttmúködések

- USAFA (USA) - kiberbiztonság

- MTC (ET) - rendészet, környezetvédelem

- WESTPOINT (USA) - hadtudomány oktatása, kiberbiztonság, terrorizmus

- MUTW (PL) - légvédelem, logisztika

- USNA (Egyesült Államok) - kiberbiztonság

- UPS (HU) - Európai Unió, terrorizmus

- WRAIR (USA) - katonai egészségügy

Az összevetés során két dolgot érdemes kiemelnünk. Egyrészt, hogy az NKE jól láthatóan más témakategóriákra fókuszál tudományos munkája során, illetve az Európai Uniós kutatások többsége nem a Hadtudományi és Honvédtisztképzó Karhoz kötődik. Ebból arra következtethetünk, hogy a HHK által kutatott témák sokkal fragmentáltabbak, így érdemes lenne olyan témákat kiválasztani, amelyekre késóbb összpontosulhat a szerzók munkája. Másrészt fontos megjegyeznünk, hogy a vizsgált intézmények közül négy is foglalkozik kiberbiztonsági kutatásokkal, ami egy kiemelkedő, aktuális és igen népszerú téma. A kiberbiztonsági területen két témakategória kerül elôtérbe: a kiberbúnözés, számítógép-védelem és kiberhadviselés („Cybercrime, Computer security, warfare”), valamint a számítógép-védelem, hackelés, virtuálissá tétel („Computer security, hacking, virtualization”). Habár az NKE-n is kiemelt figyelmet kap a kiberbiztonság területe, az NKE témakategória listáján ez mégsem tükröződik, ami azt mutatja, hogy a szerzók nem megfeleló vagy nem elengedô közleményt írnak a témában. Érdemes lenne az intézményben zajló kiberbiztonsági kutatásokat ezek alapján értékelni és megfelelóen rendezni, hogy ez a téma a nemzetközi összevetéskor egyetemünk profiljában elótúnjön. Az NKE témái közül egyezést a radikalizáció, terrorizmus és terrorelhárítás („,Radicalization, terrorist, counterterrorism") téma mutat, a vizsgálatba bevont intézmények közül a téma a 2. legjelentôsebbként jelentkezik a Westpoint amerikai akadémia profiljában. Érdemes lenne a kapcsolatot a nemzetközi együttmúködés érdekében felvenni a Westpointtal, a közös témakategória ehhez jó alapot biztosíthat, ennek következményeként a kiberbiztonsági kutatásaink is lendületet kaphatnak. 


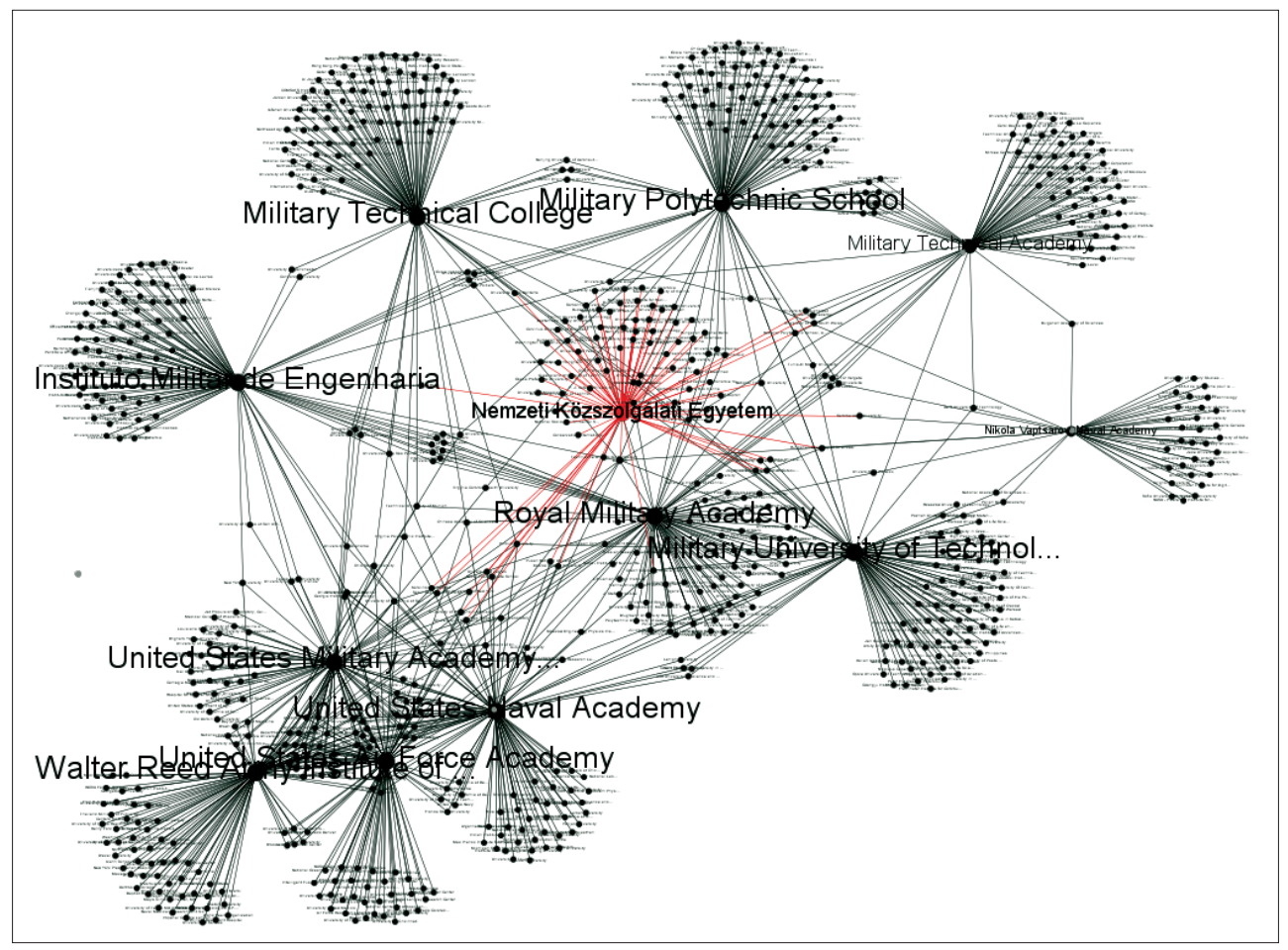

8. ábra.

Hadtudománnyal foglalkozó egyetemek publikációs hálózata

(Saját szerkesztés Scival adatok alapján)

A hálózati ábra a kutatási együttmúködéseket mutatja a vizsgált intézmények között. A hálózatban az egyes csomókat (node) az egyes intézmények, míg a köztük létrejövô kapcsolatokat (edge) az együttmúködésben megjelent közlemények jelentik. Az ábrán kitúnik az amerikai intézmények intenzív együttmúködése, ami így ezeket központi szereplókké teszi. A központi intézmények köré csoportosulnak a továbbiak, változó erôsségú kapcsolat mellett. A félperifériás, a központi intézményekhez erôsebb kapcsolattal fúződő egyetemek körébe tartozik a brazil, belga, lengyel és egyiptomi akadémia, illetve egyetem is. A perifériás intézmények csoportjában fóleg a kelet-közép-európai intézeteket találjuk. Ide tartozik az NKE is, amelynek kapcsolatait piros színnel jelöltük. Jól látszik, hogy az NKE gyenge kapcsolattal kötódik a többi vizsgált egyetemhez. Erósebb kapcsolatban áll a lengyel és a román intézménnyel, ami szintén a saját régiónk zártságát mutatja.

\section{Következtetések}

Jelen tanulmányban a hadtudományi profillal rendelkezó intézmények tudományos versenyképességét mértük. A hadtudomány jelentôs nemzetstratégiai szerepe miatt is kiemelkedó helyet foglal el, nagy részesedést vállal a legújabb technológiai 
megoldások fejlesztésében, míg az azokat támogató alapkutatások a hadipar fejlesztését célozzák többek között.

A vizsgálatba 12 intézményt vontunk be, amelyeket a QS- és a THE-rangsorok indikátorai mentén vetettünk össze. Eredményeink rávilágítanak az amerikai egyetemek dominanciájára, amit a nyugat-európai és további tengerentúli intézmények követnek. Ezen intézetek némelyike, habár jelenleg egyik sem szerepel ezen nemzetközi egyetemi rangsorokon, potenciális jelöltjei lehetnek ezen rangsoroknak a publikációs teljesítményük alapján. A nemzetközi egyetemi rangsorokon való szerepléssel pedig még a lehetôségek még szélesebb köre tárulna eléjük. Ugyanez a versenyképes berendezkedés a közép-kelet-európai országok intézményeiról nem mondható el. Kivételt jelent ez alól a varsói egyetem.

A tanulmánnyal célunk természetesen a hazai helyzet javítása, az NKE hadtudománnyal foglalkozó szerzőinek teljesítménymérése. Az eredményekból kitúnik, hogy az NKE szerzói szerényebb publikációs teljesítménnyel rendelkeznek, mint a többi, vizsgálatba bevont intézmény (kivéve a bolgárt), illetve nemzetközi beágyazottsága sem erôs. A jövóben a tudatos profilépítéssel, célzott publikációval, a nemzetközi egyetemi rangsorok által megkövetelt célértékek tudatában szükséges építkezni. A többi, erôsebb hadtudományi kutatási profillal rendelkezô intézmény ehhez jó példát szolgálhat, valamint a velük való tudományos együttmúködés, közös publikációk megjelentetése újabb lendületet adhat az NKE versenyképességének is. 


\section{MELLÉKLET}

\begin{tabular}{|c|c|c|c|c|c|c|c|}
\hline \multicolumn{4}{|c|}{$I M E(B R)$} & \multicolumn{4}{|c|}{$N V N A(B G)$} \\
\hline & Topic & $\begin{array}{l}\text { Field- } \\
\text { Weighted } \\
\text { Citation } \\
\text { Impact }\end{array}$ & $\begin{array}{c}\text { Promi. } \\
\text { nence } \\
\text { percentile }\end{array}$ & & Topic & $\begin{array}{l}\text { Field- } \\
\text { Weighted } \\
\text { Citation } \\
\text { Impact }\end{array}$ & $\begin{array}{l}\text { Promi- } \\
\text { nence } \\
\text { percentile }\end{array}$ \\
\hline 1 & $\begin{array}{l}\text { Urban Freight } \\
\text { Transport; } \\
\text { City Logistics; Cargo }\end{array}$ & 1,55 & 99,078 & 1 & $\begin{array}{l}\text { Game Theory; } \\
\text { Game of Life; } \\
\text { Pure Strategies }\end{array}$ & 0,02 & 59,611 \\
\hline 2 & $\begin{array}{l}\text { Business Information } \\
\text { Systems; Transparency; } \\
\text { Requirements } \\
\text { Engineering }\end{array}$ & 0,73 & 11,801 & 2 & $\begin{array}{l}\text { Seafarers; } \\
\text { Maritime Industry; } \\
\text { Merchant Fleet }\end{array}$ & 0,57 & 81,151 \\
\hline 3 & $\begin{array}{l}\text { Battery Electric } \\
\text { Vehicles; Alternative } \\
\text { Fuel Vehicles; } \\
\text { Electric Car }\end{array}$ & 0,49 & 99,843 & 3 & $\begin{array}{l}\text { Collision Avoidance; } \\
\text { Waterways; } \\
\text { Ships }\end{array}$ & 0,75 & 97,366 \\
\hline 4 & $\begin{array}{l}\text { Knowledge } \\
\text { Organization; } \\
\text { Paul Otlet; } \\
\text { Library Science } \\
\end{array}$ & 0 & 87,631 & 4 & $\begin{array}{l}\text { Computer Security; } \\
\text { Hacking; } \\
\text { Virtualization }\end{array}$ & 0 & 91,576 \\
\hline 5 & $\begin{array}{l}\text { Electric Vehicles; } \\
\text { Charging; Vehicle } \\
\text { Routing Problem }\end{array}$ & 0,74 & 98,624 & 5 & $\begin{array}{l}\text { Antarctic Treaty; } \\
\text { Wilderness; } \\
\text { Stationing of Troops }\end{array}$ & 2,08 & 77,283 \\
\hline
\end{tabular}

\begin{tabular}{|c|l|c|c||c|l|c|c|}
\hline \multicolumn{3}{|c||}{ MPS (DZ) } & \multicolumn{4}{c|}{$R M A(B)$} \\
\hline 1 & $\begin{array}{l}\text { Wood Pasture; } \\
\text { Quercus Suber; } \\
\text { Silvopastoral Systems }\end{array}$ & 0,84 & 87,507 & 1 & $\begin{array}{l}\text { Disaster Management; } \\
\text { Malaysia; } \\
\text { Floods }\end{array}$ & 0,39 & 37,873 \\
\hline 2 & $\begin{array}{l}\text { Pedestrian Flow; } \\
\text { Evacuation; } \\
\text { Crowds }\end{array}$ & 1,1 & 99,162 & 2 & $\begin{array}{l}\text { Image Repair; } \\
\text { Crisis Communication; } \\
\text { Organizational Crisis }\end{array}$ & 1,72 & 95,286 \\
\hline 3 & $\begin{array}{l}\text { RTL; Software Radio; } \\
\text { Rubus }\end{array}$ & 0 & 72,002 & 3 & $\begin{array}{l}\text { Suicidal Ideation; } \\
\text { Burnout; Psychological }\end{array}$ & 0,94 & 72,571 \\
\hline & $\begin{array}{l}\text { Density Measurement; } \\
\text { Dialysis Solutions; } \\
\text { Heteroskedasticity }\end{array}$ & 0 & 20,892 & 4 & $\begin{array}{l}\text { British Army; } \\
\text { Military Organization; } \\
\text { Conscription }\end{array}$ & 1,05 & 77,602 \\
\hline 5 & $\begin{array}{l}\text { OSGi; Intelligent } \\
\text { Tutoring Systems; } \\
\text { Learning Objects }\end{array}$ & 1,25 & 29,667 & 5 & $\begin{array}{l}\text { Nonprofit; } \\
\text { Charities; } \\
\text { Third Sector }\end{array}$ & 2,14 & 95,771 \\
\hline
\end{tabular}

\begin{tabular}{|c|l|c|c||c|l|c|c|}
\hline \multicolumn{3}{|c||}{ MTA (RO) } & \multicolumn{4}{c|}{ USAFA (USA) } \\
\hline 1 & $\begin{array}{l}\text { Grapheme; } \\
\text { Phonemes; } \\
\text { Syllabification }\end{array}$ & 0,29 & 77,386 & 1 & $\begin{array}{l}\text { Idea Generation; } \\
\text { Sketching; } \\
\text { Design Education }\end{array}$ & 4,14 & 97,702 \\
\hline 2 & $\begin{array}{l}\text { Narratology; } \\
\text { Unnatural Narrative; } \\
\text { Fictionality }\end{array}$ & 0,18 & 84,013 & 2 & $\begin{array}{l}\text { Plugs; } \\
\text { Spacecraft Design; } \\
\text { Electronic Design } \\
\text { Automation }\end{array}$ & 1,08 & 41,412 \\
\hline 3 & $\begin{array}{l}\text { Treebank; } \\
\text { Semantic Roles; } \\
\text { Word Segmentation }\end{array}$ & 0 & 95,447 & 3 & $\begin{array}{l}\text { Automated Vehicle; } \\
\text { Takeovers; } \\
\text { Autonomous Driving }\end{array}$ & 1,99 & 99,43 \\
\hline 4 & $\begin{array}{l}\text { Industrial Symbiosis; } \\
\text { Eco-industrial Parks; } \\
\text { Circular Economy }\end{array}$ & 0,13 & 99,788 & 4 & $\begin{array}{l}\text { Overconfidence; } \\
\text { Structured Products; } \\
\text { Measure of Risk }\end{array}$ & 0,59 & 17,803 \\
\hline 5 & $\begin{array}{l}\text { Emission Inventory; } \\
\text { Exhaust Gases; } \\
\text { Fuel Consumption }\end{array}$ & 0 & 98,734 & 5 & $\begin{array}{l}\text { Cybercrime; } \\
\text { Computer Security; } \\
\text { Warfare }\end{array}$ & 0,28 & 96,139 \\
\hline
\end{tabular}




\begin{tabular}{|c|c|c|c|c|c|c|c|}
\hline \multicolumn{4}{|c|}{$\operatorname{MTC}(E T)$} & \multicolumn{4}{|c|}{ WESTPOINT (USA) } \\
\hline 1 & $\begin{array}{l}\text { Thermal Comfort; } \\
\text { Courtyard; } \\
\text { Microclimate }\end{array}$ & 1,21 & 98,988 & 1 & $\begin{array}{l}\text { Military Academies; } \\
\text { Civil Engineer; } \\
\text { Engineering Education }\end{array}$ & 0,49 & 35,195 \\
\hline 2 & $\begin{array}{l}\text { Embodied Energy; } \\
\text { Life Cycle Assessment; } \\
\text { Green Building }\end{array}$ & 2,9 & 99,691 & 2 & $\begin{array}{l}\text { Radicalization; } \\
\text { Terrorist; } \\
\text { Counterterrorism }\end{array}$ & 2,31 & 97,801 \\
\hline 3 & $\begin{array}{l}\text { Pedestrian Flow; } \\
\text { Evacuation; Crowds }\end{array}$ & 0,33 & 99,162 & 3 & $\begin{array}{l}\text { Cybercrime; } \\
\text { Computer Security; } \\
\text { Warfare }\end{array}$ & 0,98 & 96,139 \\
\hline 4 & $\begin{array}{l}\text { Anti-Money } \\
\text { Laundering; } \\
\text { Financing of Terrorism; } \\
\text { Financial Crimes } \\
\end{array}$ & 0,18 & 90,806 & 4 & $\begin{array}{l}\text { Computer Security; } \\
\text { Hacking; } \\
\text { Virtualization }\end{array}$ & 0,76 & 91,576 \\
\hline 5 & $\begin{array}{l}\text { Arithmetics; } \\
\text { Driver; } \\
\text { Vehicles } \\
\end{array}$ & 0,76 & 15,771 & 5 & $\begin{array}{l}\text { Weapon Systems; } \\
\text { Balanced Scorecard; } \\
\text { Strategic Management }\end{array}$ & 0,63 & 21,207 \\
\hline
\end{tabular}

\begin{tabular}{|c|l|c|c||c|l|c|c|}
\hline \multicolumn{3}{|c||}{ MUTW (PL) } & \multicolumn{4}{c|}{ USNA (USA) } \\
\hline 1 & $\begin{array}{l}\text { Aerial Triangulation; } \\
\text { Photogrammetry; } \\
\text { Geographic Mapping }\end{array}$ & 1,56 & 87,22 & 1 & $\begin{array}{l}\text { Computer Security; } \\
\text { Hacking; } \\
\text { Virtualization }\end{array}$ & 0,38 & 91,576 \\
\hline 2 & $\begin{array}{l}\text { Unmanned Aerial } \\
\text { Vehicles; Precision } \\
\text { Agriculture; Orthophoto }\end{array}$ & 2,13 & 99,45 & 2 & $\begin{array}{l}\text { Cybercrime; } \\
\text { Computer Security; } \\
\text { Warfare }\end{array}$ & 2,08 & 96,139 \\
\hline 3 & $\begin{array}{l}\text { Production Logistics; } \\
\text { Army; Assembly } \\
\text { Systems }\end{array}$ & 0,29 & 40,077 & 3 & $\begin{array}{l}\text { Just War Theory; } \\
\text { Unjust War; } \\
\text { Jeff Mcmahan }\end{array}$ & 0,91 & 78,719 \\
\hline 4 & $\begin{array}{l}\text { Railway Transport; } \\
\text { Wagons; Cargo }\end{array}$ & 0,5 & 88,784 & 4 & $\begin{array}{l}\text { Mentors; } \\
\text { Formal Mentoring; } \\
\text { Protégés }\end{array}$ & 0,85 & 92,698 \\
\hline 5 & $\begin{array}{l}\text { Architectural Heritage; } \\
\text { Photogrammetry; } \\
\text { Information Modeling }\end{array}$ & 1,99 & 99,008 & 5 & $\begin{array}{l}\text { Siphons; } \\
\text { Bernoulli Theorem; } \\
\text { Potential Flow }\end{array}$ & 0,05 & 13,536 \\
\hline
\end{tabular}

\begin{tabular}{|c|l|c|c||c|l|c|c|}
\hline \multicolumn{3}{|c||}{ UPS $(\mathrm{HU})$} & \multicolumn{4}{c|}{ WRAIR (USA) } \\
\hline 1 & $\begin{array}{l}\text { European Law; Public } \\
\text { Advocate; Court of } \\
\text { Justice }\end{array}$ & 0 & 75,851 & 1 & $\begin{array}{l}\text { Sleep Deprivation; } \\
\text { Sleepiness; } \\
\text { Vigilance }\end{array}$ & 0,96 & 95,517 \\
\hline 2 & $\begin{array}{l}\text { Court of Justice; } \\
\text { Fundamental Rights; } \\
\text { Constitutional Courts }\end{array}$ & 0,32 & 85,969 & 2 & $\begin{array}{l}\text { Military Family; } \\
\text { Yom Kippur; } \\
\text { Posttraumatic Stress } \\
\text { Disorder }\end{array}$ & 1,56 & 89,465 \\
\hline 3 & $\begin{array}{l}\text { Cohesion Policy; } \\
\text { Structural Funds; } \\
\text { Multi-Level Governance }\end{array}$ & 0,22 & 83,393 & 3 & $\begin{array}{l}\text { Debriefing; } \\
\text { Medical Simulation; } \\
\text { Deliberate Practice }\end{array}$ & 2,12 & 97,843 \\
\hline $\begin{array}{l}\text { Council of Europe; } \\
\text { Minority Rights; } \\
\text { European Charter }\end{array}$ & 0 & 31,194 & 4 & $\begin{array}{l}\text { Patient Handoff; } \\
\text { Handover; } \\
\text { Miscommunication }\end{array}$ & 7,63 & 95,5 \\
\hline & $\begin{array}{l}\text { Radicalization; } \\
\text { Terrorist; } \\
\text { Counterterrorism }\end{array}$ & 1,02 & 97,801 & 5 & $\begin{array}{l}\text { Graduate Medical } \\
\text { Education; } \\
\text { Work Schedules; } \\
\text { Internship and } \\
\text { Residency }\end{array}$ & 0,82 & 94,124 \\
\hline
\end{tabular}




\section{FELHASZNÁLT IRODALOM}

Boda József, Boldizsár Gábor, Kovács László, Orosz Zoltán, Padányi József, Resperger István, Szenes Zoltán 2016. A hadtudományi kutatási irányok, prioritások és témakörök, Államtudományi Múhelytanulmányok 16 (2016). 1-23.

Defense Industry at the Heart of Innovation, NDIA. 2019. https://www.ndia.org/policy/recent-posts/2019/10/17/defense-industry-at-the-heart-of-innovation (Letöltés ideje: 2020. 11. 22.)

Gő́cze István 2014. Lehet és kell-e rendszerezni a tudományokat? Hadtudományi Szemle 7 (3): 232-250.

Gő́cze István 2015. A hadtudomány részterületeinek empirikus vizsgálata - 2. rész A mértékadó hadtudományi folyóiratok elemzése és értékelése. Hadtudomány 25 (3-4): 21-35. https://doi.org/10.17047/HADTUD.2015.25.3-4.21

Griffin, Stuart 2017 "Military Innovation Studies: Multidisciplinary or Lacking Discipline?" Journal of Strategic Studies 40 (1-2): 196-224. https://doi.org/10.1080/01402390.2016.1196358

Grissom, Adam 2006. "The future of military innovation studies." Journal of Strategic Studies 29 (5): 905-934. https://doi.org/10.1080/01402390600901067

Munk Sándor 2015. Hadtudományi kutatók és kutatási területeik: 1. rész: A hadtudomány részterületeinek empirikus vizsgála, Hadtudomány 25 (1-2). 4-16.

QS World University Rankings by Subject 2020: Methodology Top Universities. https://www.topuniversities.com/subject-rankings/methodology (Letöltés ideje: 2020. 11. 22.)

Sasvári Péter, Urbanovics Anna 2019. A tudományos publikálás alapjai. Budapest: Nemzeti Közszolgálati Egyetem, Államtudományi és Közigazgatási Kar.

Sun, Fuquan 2013. The Role of Research Institutes and Universities in Science and Technology Decision-making in China. SITC - STI Policy Briefs, 2013 (STI No. 13). https://escholarship.org/uc/item/0sm3191p (Letöltés ideje: 2020. 11. 22.)

The World University Rankings 2020: methodology Times Higher Education (THE). https://www.timeshighereducation.com/world-university-rankings/world-university-rankings -2020-methodology (Letöltés ideje: 2020. 11. 22.).

Voelz, Glenn 2014. Is Military Science "Scientific"? Joint Force Quarterly 75 (2014). 84-90. 